\title{
Correction to: Cancer driver G-protein coupled receptor (GPCR) induced $\beta$-catenin nuclear localization: the transcriptional junction
}

\author{
Jeetendra Kumar Nag ${ }^{1} \cdot$ Tatyana Rudina $^{1}$ - Myriam Maoz ${ }^{1}$ - Sorina Grisaru-Granovsky ${ }^{1}$ - Beatrice Uziely ${ }^{1}$.
} Rachel Bar-Shavit ${ }^{1}$

Published online: 20 December 2017

(C) Springer Science+Business Media, LLC, part of Springer Nature 2017

\section{Correction to: Cancer Metastasis Rev \\ https://doi.org/10.1007/s10555-017-9711-z}

The original version of this article unfortunately contained a mistake. The family name of Beatrice Uziely was mistakenly spelled as Uzieky. The correct name is now presented above.

The original article was corrected.

The online version of the original article can be found at https://doi.org/ 10.1007/s10555-017-9711-z.

\footnotetext{
Rachel Bar-Shavit

Rachelbar@ekmd.huji.ac.il

1 Sharett Institute of Oncology, Hadassah-Hebrew University Medical Center, POB 1200, 91120 Jerusalem, Israel
} 